\title{
Diversity of zooplankton in Dekhu reservoir from Aurangabad, Maharashtra
}

\author{
*Gajanan Sontakke and Satish Mokashe** \\ *Padambhushan Dr. Vasanraodada Patil Mahavidyalaya, Tasgaon, Sangli (Maharashtra), INDIA \\ **Dr. Babasaheb Ambedkar Marathwada University Aurangabad (Maharashtra), INDIA \\ *Corresponding author. E-mail: sgajuk@gmail.com
}

Received: November 16, 2013; Revised received: March 20, 2014; Accepted: April 12, 2014

Abstract: Zooplanktons by their heterotrophic activity play a key role in the cycling of organic materials in aquatic ecosystems and are used as bioindicators of environmental quality. The present study was carried out from February 2009 to January 2010 which deals with diversity and abundance of zooplankton in Dekhu reservoir from Aurangabad district. A total 25 species of zooplankton were recorded in which rotifers were more abundant with 11 species followed by copepods and cladocerans 6 species each and 2 species of Ostracods. Results indicated that Dekhu reservoir is more productive.

\section{Keywords: Dekhu reservoir, Diversity, Zooplankton}

\section{INTRODUCTION}

For a better understanding of the role of zooplankton as a function of the ecosystem. The seasonal fluctuations of zooplankton populations can be expressed by various quantitative parameters such as population density, biomass and biochemical compounds. According to Riccardi and Mangoni (1999), each parameter emphasizes a certain characteristic, the knowledge of which is essential to evaluate the role of zooplankton in that particular ecosystem. In India, considerable work has been done on ecology and seasonal distribution of zooplankton than other tropical and sub tropical countries (Battish, 1992; Ranga Reddy, 2001; Slathia and Dutta, 2013). Zooplankton by their heterotrophic activity plays a key role in the cycling of organic materials in aquatic ecosystems and are used as bioindicators of environmental quality. The present paper deals with diversity of zooplankton in Dekhu freshwater reservoir from Aurangabad district.

\section{MATERIALS AND METHODS}

Dekhu reservoir is located (latitude $20^{\circ} 6{ }^{\prime} 19^{\prime \prime} \mathrm{N}$ and longitude $74^{0} 55^{\prime} 58^{\prime}$ E) near Bhatana village, Tal. Vaijapur in Aurangabad district. This reservoir is mainly used for irrigation and aquaculture. The zooplankton samples were collected twice in month between 7 to 8 am by using plankton net of mesh size $64 \mu$ for a period of one year, from February 2009 to January 2010. The collected samples were kept in plastic bottles containing $4 \%$ formaldehyde. Zooplankton identification is done by following systematic keys of Pennak (1978),Edmondson (1992), Battish (1992) and Altaff (2004). Main characters are considered for identification are lorica, corona and type of trophi for rotifers; antennules, postabdomen, number and arrangement of spines, location of lateral setae and rostrum for cladocera; antennules, antenna, caudal setae, and endopodite for copepoda and antenna, valve shape and setae for ostracods.

Population density was quantified by Drop count method of Lackey (1938) and was calculated using the following formula of Lackey (1938) :

$$
\mathrm{N}=\mathrm{n} \times \mathrm{v} / \mathrm{V}
$$

Where,

$\mathrm{N}=$ Total no. of organisms/ lit of water filtered,

$\mathrm{n}=$ Number of zooplankton counted in $1 \mathrm{ml}$ plankton sample,

$\mathrm{v}=$ Volume of concentrate plankton sample $(\mathrm{ml})$,

$\mathrm{V}=$ Volume of total water filtered through $(\mathrm{L})$

\section{RESULTS AND DISCUSSION}

A total 25 species of zooplankton were recorded from Dekhu reservoir. Among 25 species, Rotifera was dominant with 11 species followed by 6 species of Copepoda, 6 species of Cladocera and 2 species of ostracod (Table 1). Monthly recorded Zooplankton population is depicted in table 2 .

Rotifera: Rotifers play a vital role in the trophic tiers of freshwater impoundments and serve as living capsule of nutrition (Suresh Kumar et al., 1999). In the present study they dominated with 11 species as compared to other groups of zooplankton. Taxonomic dominance has been reported in several water bodies (Kudari et al., 2005; Kanagasabhapati and Rajan, 2010). This pattern is common in lakes, ponds, reservoirs and rivers (Neves et al., 2003). The population density of rotifers was rich in summer season (880 org/lit) and less in winter season (366 org/lit). The number of Rotifers increased in summer which may be due to the higher population of bacteria and organic matter of dead and decaying vegetation (Majagi and Vijaykumar, 2009). Segers (2003) highlighted the dominance of rotifer population which 
was due to its preference for warm waters. Planktonic rotifers have a very short life cycle under favorable conditions of temperature, food and photoperiod. Since the rotifers have short reproductive stages they increase in abundance rapidly under favorable environmental conditions (Dhanapathi, 2000).

Copepoda: Freshwater copepods constitute one of the major zooplankton communities occurring in all types of water bodies. They serve as food to several fishes and play a major role in ecological pyramids. In the present study, 6 species were recorded. Copepods showed higher population density in summer season (447 org/lit) and lower in mansoon (32 org/lit). This

Table 1. Checklist of Zooplankton from Dekhu fresh water reservoir.

\section{Rotifera:}

1. Brachionus calyciflourus (Pallas, 1834)

2. Brachionus caudatus (Barrois and Daddy, 1894)

3. Brachionus forficule (Weirzejski, 1891)

4. Brachionus angularis (Gosse, 1851)

5. Brachionus bidentata (Jokubsky, 1912)

6. Trichotria tetractis (Ehrenberg, 1830)

7. Polyarthra major (Burckhardt, 1900)

8. Filinia terminalis (Plate, 1886)

9. Asplanchna priodonta (Gosse, 1850)

10. Lecane luna (Muller, 1776)

11. Trichocerca SPP. (Lamarck, 1801)

Cladocera:

1. Moina macrocopa (Straus, 1820)

2. Moina micrura (Kurz, 1874)

3. Diaphanosoma excisum ( Sars, 1865)

4. Daphnia longirimis ( Sars, 1861)

5. Leydigo acanthocercoids (Fischer, 1854)

6. Ceriodaphnia cornuta (Sars, 1885) Copepoda:

1. Heliodiaptomus viduus (Gurney, 1916)

2. Trpocyclop prasinus (Fischer, 1886)

3. Paracyclop fermbrialis (Fischer, 1853)

4. Mesocyclop leucarti (Claus, 1857)

5. Eodiaptomus japonicus (Burckhardt, 1913)

6. Mesocyclops hyalinus (Rehberg, 1880

\section{Ostracoda:}

1. Hemicypris fossulata (Baird, 1845)

2. Cyclocypris globosa (Baird, 1845) pattern of seasonal fluctuation of copepods has also been observed by Mahor (2011) in Trigha reservoir of Gwalior.

Abundance of copepods in summer and winter is due to the lake which is rich in organic matter supporting higher number of Cyclopoids, thus suggesting their preponderance in higher trophic state of water. Similar observations are made by Somani and Pejavar (2004) in Masunda Lake. Absence of parthenogenetic form of copepod might be responsible for their low population density in mansoon season (Mustapha, 2009).

Cladocera: Cladocerans are the most useful and nutritive group of crustaceans for higher members of fishes in the food chain. In the present study, a total of 6 species were recorded. The population densities of cladocera were higher in monsoon season (39 org/lit) and lower in winter (35 org/lit.). Abundance has also been earlier reported in monsoon season and lower in summer by Pawar and Pulle (2005) in Pethwadaj dam of Nanded district.

Ostracoda: Ostracod represented very low diversity and population density as compared to other groups of zooplankton. In the present study, 2 species of ostracods were recorded. The population density was higher in summer season (23 org/lit) and less in winter (15 org/lit). This result has also been observed by Sukand and Patil (2004) in Fort Lake of Belgaum and Kedar et al. (2008) in Rishi freshwater lake of Washim district.

Among all the zooplankton, rotifer has maximum diversity and population density in all the seasons. The dominance of rotifers in the lake was due to the continuous supply of food material which in turn indicates the eutrophic nature of the lake (Sukand and Patil, 2004) and that of Sona Dighi reservoir (Naz and Najia, 2008).

Average number of Copepods were noticed during mansoon and winter, but were too less in summer season. As compared to rotifera and copepoda, population density of Cladocera and Ostracod was very low in all the seasons and they did not show the remarkable seasonal fluctuation.

In this study, all over population of zooplankton was high in summer and winter season; and low in mansoon season. Copepods and rotifers were dominated over Cladocera and Ostracod by population throughout the year. Similar observations have been made by Das (2002). Primary production is responsible for increasing the population density of zooplanktons in summer season. Normally mansoon is associated with lower population densities due to its dilution effect and

Table 2. Monthly variations in Zooplankton Population Density (org/lit) in Freshwater Reservoirs of Dekhu during Feb. 2009 to Jan. 2010.

\begin{tabular}{lccc}
\hline Month/Group & Summer & Monsoon & Winter \\
\hline Rotifera (org/lit) & 880 & 496 & 366 \\
Cladocera (org/lit) & 38 & 39 & 35 \\
Copepoda (org/lit) & 447 & 32 & 261 \\
Ostracoda (org/lit) & 23 & 19 & 15 \\
\hline
\end{tabular}


decreased photosynthetic activities by primary production. Similar results were reported by Salve and Hiware (2010) in Wan reservoir of Nagpur. The abundance of some zooplankton in the aquatic food web has been reported to indicate eutrophication (Halbach et al., 1983).

The present study concluded the dominance of Rotifera and Copepoda indicating the eutrophication of Dekhu water body.

\section{REFERENCES}

Altaff, K. (2004). A Mannual of zooplankton, Sponsored by the University Grant commission, New Delhi.

Battish, S.K. (1992). Freshwater Zooplankton of India. Oxford and IBH Publishing Co. Pvt. Ltd., New Delhi, i-iv, pp, 233.

Das, S. K. (2002). Primary production and zooplankton biodiversity in brackish water shrimp culture pond. $J$. Ecobiology, 14(4): 267-271.

Dhanapathi, M.V.S.S.S. (2000). Taxonomic notes on the rotifers form India (from 1889-2000). Indian Association of Aquatic Biologists (IAAB), Hyderabad.

Edmondson, W.T. (1992). Freshwater Biology, $2^{\text {nd }}$ Edition, John Willey and Sons. London. pp, 657-734.

Halbach, U., Siebart, M., Wastmayear, M. and Wissel, C. (1983). Population ecology of rotifers as a bioassay tool for ecotoreicological testes in aquatic environment. Ecotoreical. Environ. Safety, 7: 484-513.

Kanagasabhapati, V. and Rajan, M. K. (2010). A Preliminary survey of plankton in Irrukkangudi reservoir, Virudhnagar District, T.N. J. of Phytology, 2 (3): 63-72.

Kedar, G.T., Patil, G.P. and Yeole, S.M. (2008). Effect of physicochemical factors on the seasonal abundance of zooplankton population in Rishi Lake. Proceedings of Taal 2007. The $12^{\text {th }}$ world lake conference, 88-91.

Kudari, V.A., Kadadevaru, G.G. and Kanamadu, R.D. (2005). Zooplankton composition in some ponds of Haveri district, Karnataka. Zoo's Print Journal, 20 (12):2094-2099.

Lackey, J.B. (1938). The manipulation and counting of river of river plankton and changes in some organisms due to formalin preservation. Public Health Repts., 53:20802093.

Majagi, G. and Vijaykumar, K. (2009). Ecology and abundance in Karanja reservoir. Environ. Monit. Asses., 152:137-144

Mahor, R. K. (2011). Diversity and seasonal fluctuation of zooplankton in freshwater reservoir Tighra Gwalior
(M.P.). Internat. Referred Research Journal, 1(17): 47-48.

Mustapha, M. K. (2009). Zooplankton assemblage of Oyun reservoir, Offa, Nigeria. Rev. Biol. Trop. (Int). J. Trop. Biol., 57 (4): 1027-1047.

Naz, S and Najia, S (2008). Study on the zooplankton of Sona Dighi in Rajshahi, Bangladesh. Univ. J. Zool. Rajshahi Univ. 27, 07-11.

Neves, I. F., Rocha, O., Rocha, K.F. and Pinto, A.A. (2003). Zooplankton community structure of two marginal lakes of the river Cauba (Mato Grasso, Brazil) with analysis of Rotifera and Cladocera diversity Brazil. Journal of Biology, 63(3):329-343.

Pawar, S. K. and Pulle, J. S. (2005). Qualitative and quantitative study of zooplankton in Pethwadaj Dam, Nanded district (Maharashtra) India. Journal of Aquatic Biology, 20 (2):53-57.

Pennak, R. W. (1978). Freshwater Invertebrates of United States. $2^{\text {nd }}$ Edition, John Wiley and Sons Inc. pp, 421.

Ranga Reddy, Y. (2001). Zooplankton diversity: freshwater planktonic Copepoda with key to common Calanoid and Cyclopoid genera in India. In, water quality assessment, biomonitoring and zooplankton diversity. Sharma, B.K (Ed) pp. 174-189.

Riccardi, N. and Mangoni, M. (1999). Consideration on the biochemical composition of some freshwater zooplankton species. J. Limnology, 58(1): 58-65.

Salve, B. and Hiware, C. (2010). zooplankton diversity of wan reservoir, Nagpaur (MS) India. Trends Research in Science and Technology, 2 (1):39-48.

Segers, H. (2003). A biogeographical analysis of rotifers of the genus Trichocerca Lamarck, 1801 with notes on taxonomy. Hydrobiologia, 500: 103-114.

Slathia, D. and Dutta, S.P.S. (2013). Hydrobiological study of subtropical shiwalik lake, Jammu, J and K, India. International Journal of Chemical, Environmental \& Biological Sciences (IJCEBS), 1(1):143-148.

Somani, V. and Pejavar, M. (2004). Crustacean zooplanktons of Lake Masunda, Thane, Maharashtra. J. Aqua. Biol., 1(19):57-60.

Sukand, B.N. and Patil, H.S. (2004). Water quality assessment of Fort lake of Belgaum (Karnataka) with special reference to zooplankton. J. of Env. Biol., 25(1): 99- 102.

Suresh Kumar, Altaff, R.K. and Raghunathan, M.B. (1999). New record of a Chydorid Cladoceran, pleuroxuy Aduncus jurine (1920), from Chennai, South India, with the description of the Development stages, J. Aqua. Biol., 14 (1\& 2):7-10. 